NASA/CR-1999-202353

Flow Quality Measurements in an Aerodynamic Model of NASA Lewis' Icing Research Tunnel

Victor A. Canacci and Jose C. Gonsalez

NYMA, Inc., Brook Park, Ohio 
Since its founding, NASA has been dedicated to the advancement of aeronautics and space science. The NASA Scientific and Technical Information (STI) Program Office plays a key part in helping NASA maintain this important role.

The NASA STI Program Office is operated by Langley Research Center, the Lead Center for NASA's scientific and technical information. The NASA STI Program Office provides access to the NASA STI Database, the largest collection of aeronautical and space science STI in the world. The Program Office is also NASA's institutional mechanism for disseminating the results of its research and development activities. These results are published by NASA in the NASA STI Report Series, which includes the following report types:

- TECHNICAL PUBLICATION. Reports of completed research or a major significant phase of research that present the results of NASA programs and include extensive data or theoretical analysis. Includes compilations of significant scientific and technical data and information deemed to be of continuing reference value. NASA's counterpart of peerreviewed formal professional papers but has less stringent limitations on manuscript length and extent of graphic presentations.

- TECHNICAL MEMORANDUM. Scientific and technical findings that are preliminary or of specialized interest, e.g., quick release reports, working papers, and bibliographies that contain minimal annotation. Does not contain extensive analysis.

- CONTRACTOR REPORT. Scientific and technical findings by NASA-sponsored contractors and grantees.
- CONFERENCE PUBLICATION. Collected papers from scientific and technical conferences, symposia, seminars, or other meetings sponsored or cosponsored by NASA.

- SPECIAL PUBLICATION. Scientific, technical, or historical information from NASA programs, projects, and missions, often concerned with subjects having substantial public interest.

- TECHNICAL TRANSLATION. Englishlanguage translations of foreign scientific and technical material pertinent to NASA's mission.

Specialized services that complement the STI Program Office's diverse offerings include creating custom thesauri, building customized data bases, organizing and publishing research results ... even providing videos.

For more information about the NASA STI Program Office, see the following:

- Access the NASA STI Program Home Page at http://www.sti.nasa.gov

- E-mail your question via the Internet to help@sti.nasa.gov

- Fax your question to the NASA Access Help Desk at (301) 621-0134

- Telephone the NASA Access Help Desk at (301) 621-0390

- Write to:

NASA Access Help Desk

NASA Center for AeroSpace Information 7121 Standard Drive

Hanover, MD 21076 
NASA/CR-1999-202353

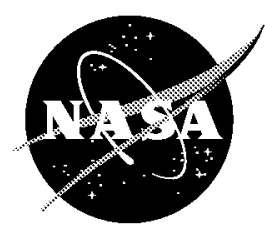

Flow Quality Measurements in an Aerodynamic Model of NASA Lewis' Icing Research Tunnel

Victor A. Canacci and Jose C. Gonsalez NYMA, Inc., Brook Park, Ohio

Prepared for the

31st Joint Propulsion Conference and Exhibit sponsored by AIAA, ASME, SAE, and ASEE

San Diego, California, July 10-12, 1995

Prepared under Contract NAS3-27186

National Aeronautics and

Space Administration

Lewis Research Center 


\section{Acknowledgments}

The authors recognize the IRT Long Range Planning Team, and the many test conductors, designers, machinists, and model craftsmen who have contributed to the success of the SMIRT program. The authors also extend their special gratitude to Glenn A. Cancilla for modifying the test section, thus making data acquisition a more efficient process, and to Gerald A. Carek and David W. Sheldon for numerous consultations and for overseeing the design and fabrication of the tunnel.

Available from

NASA Center for Aerospace Information 7121 Standard Drive

Hanover, MD 21076

Price Code: A03
National Technical Information Service 5285 Port Royal Road Springfield, VA 22100 Price Code: A03 


\title{
FLOW QUALITY MEASUREMENTS IN AN AERODYNAMIC MODEL OF NASA LEWIS' ICING RESEARCH TUNNEL
}

\author{
Victor A. Canacci and Jose C. Gonsalez \\ NYMA, Inc. \\ Brook Park, Ohio 44142
}

\begin{abstract}
Summary
As part of an ongoing effort to improve the aerodynamic flow characteristics of the Icing Research Tunnel (IRT), a modular scale model of the facility was fabricated. This $1 / 10$ th-scale model was used to gain further understanding of the flow characteristics in the IRT. The model was outfitted with instrumentation and data acquisition systems to determine pressures, velocities, and flow angles in the settling chamber and test section. Parametric flow quality studies involving the insertion and removal of a model of the IRT's distinctive heat exchanger (cooler) and/or of a honeycomb in the settling chamber were performed. These experiments illustrate the resulting improvement or degradation in flow quality.
\end{abstract}

\section{Introduction}

The Icing Research Tunnel (IRT) at the NASA Lewis Research Center (ref. 1) has been performing icing programs for more than 50 years. Currently, the IRT (fig. 1) is the largest, fastest, and most preferred refrigerated wind tunnel in the world. Renovations have been planned to ensure that the IRT remains the world's premier icing facility well into the next century. These improvements include the installation of new spray bars with improved spray capabilities and the replacement of the facility heat exchanger (cooler). Improvements that have already been implemented include the installation of new fan blades (increasing the test section velocity from 300 to $430 \mathrm{mph}$ ) and modernization of the control room.

Previous flow quality measurements (ref. 2) indicated that installation of flow-conditioning devices in the IRT were necessary to meet new flow quality goals. Work by other researchers indicated that the addition of a deep honeycomb would improve flow quality (ref. 3). Therefore, the insertion of a honeycomb in the IRT settling chamber was recommended to correct disrupted flow entering the contraction. Because full-scale experiments were deemed too time consuming and costly, a 1/10th-scale aerodynamic model of the IRT (without icing capabilities) to test flow improvement concepts was constructed. This Scale Model Icing Research Tunnel (SMIRT) aerodynamically duplicates the geometry of the tunnel shell, cooler, and spray bars that make the IRT a unique facility. Models of the IRT's eight spray bars and its characteristic W-shaped cooler (fig. 2) can be inserted and removed easily to allow measurement of changes in the flow quality.

Preliminary assessments of the cooler replacement and honeycomb installation proposed for the full-scale IRT were conducted in the SMIRT. These experiments were designed to determine how a honeycomb would affect the tunnel flow characteristics. In addition, baseline data needed to be obtained for the SMIRT. Hot wire instrumentation was used to obtain data at the test section centerline and in the settling chamber at the plane of the spray bars. Additional test section data were acquired with pressure rakes. These experiments were conducted at test section Mach numbers of $0.1,0.3$, and 0.5 with different cooler/honeycomb configurations. The specific objectives of this paper follow:

(1) Introduce the SMIRT facility and describe its salient characteristics and performance parameters.

(2) Present velocity profiles (computed from measured pressure data) in the test section with different cooler/ honeycomb configurations.

(3) Present hot wire data for the settling chamber and the test section with different cooler/honeycomb configurations.

(4) Document flow quality changes realized from installing a honeycomb in the settling chamber.

To establish correlations, a future paper will compare measurements presented here with those taken at similar locations in the full-scale IRT. If comparisons are favorable, they will validate the SMIRT as an accurate model of the IRT. These measurements will be useful in the design of full-scale facility improvements (i.e., new cooler, new flow conditioners, etc.). 


\section{Symbols}

$H_{S C} \quad$ settling chamber height, in.

$H_{T S} \quad$ test section height, in.

$L / D \quad$ length-to-cell width ratio for honeycomb cells

MTS $\quad$ test section Mach number

$n \quad$ number of data points

$R \quad$ magnitude of velocity vector, $\mathrm{ft} / \mathrm{sec}$

$T I_{U} \quad$ axial turbulence intensity, percent

$T_{V} \quad$ pitch turbulence intensity, percent

$U_{H W} \quad$ mean axial velocity measured with hot wire probes, $\mathrm{ft} / \mathrm{sec}$

$U_{H W}^{\prime}$ instantaneous axial velocity measured with hot wire probes, $\mathrm{ft} / \mathrm{sec}$

$U_{P R} \quad$ mean axial velocity computed from pressure rake measurements, $\mathrm{ft} / \mathrm{sec}$

$V_{H W} \quad$ mean pitch velocity measured with hot wire probes, $\mathrm{ft} / \mathrm{sec}$

$V^{\prime} H W \quad$ instantaneous pitch velocity measured with hot wire probes, $\mathrm{ft} / \mathrm{sec}$

$V_{S C} \quad$ settling chamber velocity used to normalize hot wire velocity data, $\mathrm{ft} / \mathrm{sec}$

$V_{T S}$ test section velocity used to normalize both hot wire and pressure rake velocity data, $\mathrm{ft} / \mathrm{sec}$

$X_{H W}$ vertical measurement location for hot wire experiments, in.

$X_{P R} \quad$ vertical measurement location for pressure rake experiments, in.

$\alpha H W \quad$ pitch flow angle from hot wire measurements, deg

$\sigma U \quad$ standard deviation of hot wire axial velocity data, $\mathrm{ft} / \mathrm{sec}$

$\sigma V \quad$ standard deviation of hot wire pitch velocity data, $\mathrm{ft} / \mathrm{sec}$

\section{Description of Facility}

NASA Lewis Research Center's Engineering Directorate designed the Scale Model Icing Research Tunnel in 1992. The tunnel was fabricated onsite by machinists and model craftsmen from Lewis' Fabrication Division. This $1 / 10$ th-scale model was designed to be modular so that flow-conditioning devices or entire sections could be easily installed and removed. The walls were assembled of 0.5-in.-thick clear acrylic plastic sheet supported by an aluminum frame (fig. 3). The length, width, and height of the settling chamber are 16.6, 35, and 31.4 in., and the length, width, and height of the test section are 24,10.8, and 7.2 in., respectively. A 14:1 contraction connects the settling chamber to the test section.

The SMIRT turning vanes, which were machined from phenolic tubing, are supported by aluminum structures. The cooler was constructed to conform geometrically to the full-scale cooler. The large refrigerant manifolds were modeled with solid wood fairings, and the tube banks were simulated with a 4-mesh screen (four 0.035-in.-diameter wires per inch). The horizontal spray bars were modeled with 0.75-in.-diameter aluminum cylinders, and the vertical supports were machined from aluminum bar stock. It should be noted that the cooler and spray bars in the SMIRT are 
nonfunctional geometric representations only and that the spray bars were not installed during any of the experiments described in this paper.

Completed tunnel sections were tested in an open-loop configuration because the fan sections were unavailable. For operation in this open-loop configuration (fig. 4), the downstream side of the SMIRT's diffuser was attached to an 18-in.-diameter exhaust line capable of providing a 26 -in.-Hg vacuum. An orifice plate restricted mass flow through the tunnel to a maximum rate of $25 \mathrm{lb} / \mathrm{sec}$. An 18 -in.-diameter butterfly valve and a 6 -in.-diameter bypass valve controlled the flow through the tunnel. The maximum test section velocity was $650 \mathrm{ft} / \mathrm{sec}$ (Mach 0.6), although data were not taken at this condition. Mach numbers were maintained to within \pm 0.003 throughout the speed range. The total pressure through the tunnel remained equal to atmospheric pressure $(\approx 14.4$ psia), while the static pressures fell below atmospheric levels. Total temperature through the tunnel remained equal to the ambient temperature in the test cell $\left(\approx 70^{\circ} \mathrm{F}\right)$.

The settling chamber was configured such that honeycombs of various thicknesses could be installed. Two different thicknesses of 0.188 -in. hexagonal cell honeycomb were tested: 3 -in. (length-to-diameter ratio, $L / D=16$ ) and 6 -in. $(L / D=32)$. These honeycomb sheets were positioned so that their exit faces were $6 \mathrm{in}$. downstream of the settling chamber inlet plane. Table I describes the various cooler/honeycomb configurations and test section Mach numbers for which data were obtained.

\section{Instrumentation and Data Acquisition}

Two total pressure rakes positioned on the centerline 11.25 in. downstream of the test section inlet plane (fig. 4) acquired pressure data in the test section. These rakes consist of fourteen 0.063 -in.-diameter Pitot tubes spaced 0.25 in. apart. In addition, pressure taps (0.020-in. diameter) in the walls of the test section (five positions) and diffuser (18 positions) were used to acquire static pressure values. The pressures were measured by an electronically scanned system (using 15-psid modules) and were recorded on a mainframe computer via the facility's standard data acquisition system. The total temperature at the entrance of the tunnel was measured by a Type K thermocouple. Although not presented in this paper, tuft and smoke flow visualization data were also recorded.

Hot wire measurements were obtained with commercially available probes and equipment. Measurements were taken $12.0 \mathrm{in}$. downstream of the test section inlet plane. In the settling chamber, measurements were taken 13.63 in. downstream of the chamber's inlet plane (when a honeycomb was installed, this corresponded to 7.63 in. downstream of the exit face). Two hot wire X-probes $\left(0.00015\right.$-in.-diameter tungsten wires oriented at $\pm 45^{\circ}$ with respect to the flow direction) were used for the majority of the measurements. A single-wire probe $(0.00015$-in.-diameter tungsten wire vertically oriented at $90^{\circ}$ with respect to the flow direction) was used for the inverted probe measurements that are reviewed in the DISCUSSION OF RESULTS section. Each hot wire was connected to a constant temperature anemometer via a 60-ft low-impedance coaxial cable. Each anemometer was equipped with its own signal conditioner for lowpass filtering, direct-current (DC) offsetting, and amplifying. A four-channel, 12-bit analog-to-digital converter with an input range of $\pm 5 \mathrm{~V}$ was used to digitize the signal-conditioned anemometer bridge voltages. A personal computer with commercially available software was used to control the data acquisition process and to store the data.

The data acquisition sampling frequencies, low-pass filter frequencies, amplifier gains, and DC offsets for the hot wire measurements are given in table II for all configurations and test section speeds. In addition, the particular hot wire probe used for the measurements is indicated (X-probe 1, X-probe 2, or a single-wire probe). Before signal conditioning, raw anemometer bridge voltages for all hot wire probes typically varied between 0.8 and $1.9 \mathrm{~V}$ for velocities of 0 and $600 \mathrm{ft} / \mathrm{sec}$, respectively. For all measurement locations, 10240 data points were taken. This provided either 2.044 or $5.12 \mathrm{sec}$ of data depending on the sampling frequency ( 5000 or $2000 \mathrm{~Hz}$, respectively). Low-pass filter frequencies were always set below or at one-half the sampling frequency to prevent aliasing.

Before the hot wire probes were used in the SMIRT, they were calibrated in a free-jet facility at speeds up to $230 \mathrm{ft} / \mathrm{sec}$. Additional calibration data (up to speeds of $600 \mathrm{ft} / \mathrm{sec}$ ) were obtained in the SMIRT test section for velocity data from a calibrated pressure rake. The lower speed calibration data were used for the settling chamber measurements. The higher speed calibration data were used for the test section measurements.

\section{Data Reduction}

The two total rakes and a single wall static tap axially centered in the test section measured total and static pressure data. These data were used to compute velocities via compressible flow equations. The velocity calculated at the test 
section centerline, $V_{T S}$, was used to normalize the pressure rake velocity data $U_{P R}$ presented in this paper.

For hot wire data reduction, the recorded fluctuating anemometer voltages were converted into fluctuating velocities. For the single-wire probe, the calibration curve provided the direct transfer function between the anemometer voltage and the instantaneous axial velocity $U_{H W}^{\prime}$. For the X-probes, anemometer bridge voltages and the calibration data were used in a system of equations that was solved simultaneously for an instantaneous axial velocity component, $U_{H W}^{\prime}$, and an instantaneous pitch velocity component $V^{\prime} H W$. Elaborating on the details of this system of equations and its solution is beyond the scope of this paper (ref. 4).

Once the velocities were generated from the voltage data, statistical analysis was done on the fluctuating velocity data. Of primary interest were the mean axial velocity $U_{H W}$, the pitch flow angle $\alpha H W$, the axial turbulence intensity $T I_{U}$, and the pitch turbulence intensity $T I_{V}$. Definitions of these quantities follow:

$$
\begin{gathered}
U_{H W}=(1 / n)-\sum_{1}^{n} U_{H W}^{\prime} \\
V_{H W}=(1 / n)-\sum^{n}{ }_{1} V_{H W}^{\prime} \\
R=\left[U_{H W}{ }^{2}+V_{H W}{ }^{2}\right]^{(1 / 2)} \\
\alpha H W=\tan ^{-1}\left(V_{H W} / U_{H W}\right) \\
\sigma_{U}=\left[(1 / n)-\sum^{n}{ }_{1} U_{H W}^{\prime}{ }^{2}-U_{H W}{ }^{2}\right]^{(1 / 2)} \\
\sigma_{V}=\left[(1 / n)-\sum^{n}{ }_{1} V_{H W}{ }^{2}-V_{H W}{ }^{2}\right]^{(1 / 2)} \\
T I_{U}=\sigma U / R \times 100 \text { percent } \\
T I_{V}=\sigma V / R \times 100 \text { percent }
\end{gathered}
$$

where $n$ is the number of data points, $R$ is the magnitude of the velocity vector, $V_{H W}$ is the mean pitch velocity measured with hot wire probes, and $\sigma_{u}$ and $\sigma_{v}$ are the standard deviation of the hot wire axial and pitch velocity data, respectively.

\section{Accuracy of Measurements}

The pressure-measuring system used to acquire the test section total and static pressures had a measurement uncertainty of $\pm 0.02 \mathrm{psi}$, and the thermocouple used to measure the total temperature had a measurement uncertainty of $\pm 2{ }^{\circ} \mathrm{F}$. These uncertainties (when propagated through the equations used to compute the velocity ratios) yielded a velocity ratio uncertainty of \pm 0.015 at a test section Mach number, $M_{T S}$, of 0.3 and an uncertainty of \pm 0.006 at an $M_{T S}$ of 0.5 .

The hot wire data presented in this paper were intended to be first-order quantitative data only. As a result, a formal uncertainty analysis was not performed. However, level of confidence bounds for the presented data were determined from repeated measurements and additional test data were obtained to validate the calibration curves. These bounds follow: 
Settling chamber measurements

Mean axial velocity ratio, $U_{H W} / V_{S C} \ldots \ldots \ldots \ldots \ldots \pm 0.05$

Pitch flow angle, ouw, deg

Axial turbulence intensity, $T I_{U}$, percent

$\pm 0.8$

Pitch turbulence intensity, $T I_{V}$, percent

$\pm 0.8$

Test section measurements

Mean axial velocity ratio, $U_{H W} / V_{T S}$ $\pm 0.005$

Pitch flow angle, $\alpha_{H W}, \operatorname{deg} \ldots \ldots \ldots \ldots \ldots \ldots \ldots \ldots \ldots \ldots . . . \pm 0.4$

Axial turbulence intensity, $T I_{U}$, percent $\ldots \ldots . . \pm 0.1$

Pitch turbulence intensity, $T I_{V}$, percent $\ldots \ldots \ldots \pm 0.1$

\section{Discussion of Results}

Figure 5 presents the velocity ratio profiles derived from pressure data taken in the SMIRT test section for the various cooler/honeycomb configurations. The data for two Mach numbers show that the profiles are flat and similar regardless of the cooler/honeycomb configuration.

Figures 6 and 7 show hot wire data results for the SMIRT settling chamber at two different test section Mach numbers, 0.3 and 0.5 , for different cooler/honeycomb combinations. Figures 8, 9, and 10 show hot wire data results for the SMIRT test section at test section Mach numbers of $0.1,0.3$, and 0.5 for different cooler/honeycomb combinations. It should be mentioned that the hot wire data profiles presented were constructed by averaging two profiles. One profile was obtained by traversing the probe from the ceiling to the floor and the other by traversing from the floor to the ceiling.

The mean axial velocities $U_{H W}$ shown in figures 6(a), 7(a), 8(a), 9(a), and 10(a) were normalized according to the settling chamber and test section velocities listed in the captions. The settling chamber normalizing velocities $V_{S C}$ were taken to be the maximum hot wire velocities measured for the configuration with the cooler but without a honeycomb.

The test section normalizing velocities $V_{T S}$ were calculated from the nominal test section Mach number and the total temperature in the test section.

Figures 6(a) and 7(a) show the effects of a cooler and honeycomb on the mean axial velocity profiles in the SMIRT settling chamber. As would be expected, the mean profiles were rather well behaved when the cooler was absent but were distorted when the cooler was present. Increasing honeycomb thickness was ineffective in minimizing these distortions introduced by the W-shaped cooler. In the test section, the mean velocity profiles did not suffer from significant distortion when the cooler was present (figs. 8(a), 9(a), and 10(a)). This indicates that the settling chamber distortions did not propagate into the test section. In addition, the test section mean velocity profiles were not significantly affected by the insertion of a honeycomb. The negative-sloped gradients seen in the test section velocity profiles prompted inverted probe measurements. The inverted probe data produced positive-sloped gradients. This result supports the theory that the gradients were caused by probe support interference and by possible leakage through the tunnel wall/ probe support penetration.

Figures 6(b) and 7(b) show pitch flow-angle data in the settling chamber for the different cooler/honeycomb configurations tested. It should be noted that the pitch angle was positive when the flow velocity vector pointed toward the tunnel ceiling and negative when it pointed toward the floor. The flow-angle profiles measured in the absence of the cooler show smooth and symmetric trends. The S-shape of the profile results from the fact that the hot wire probe was sensing upstream influence from the contraction. Near the floor and ceiling of the settling chamber (ratios of vertical measurement location to settling chamber height, $X_{H W} / H_{S C}=0.0$ and 1.0), flow streamlines traveled parallel to the floor and ceiling surfaces, which resulted in near-zero pitch angles. Around $X_{H W} / H_{S C}=0.25$ and 0.75 , the streamlines converged toward the settling chamber centerline; hence, the positive pitch angles were around $X_{H W} / H_{S C}=0.25$, and the negative pitch angles were around $X_{H W} / H_{S C}=0.75$. The flow streamlines near the center of the settling chamber remained on the centerline, and the resulting flow angles were near zero. Flow-angle measurements with the cooler installed showed erratic, nonsymmetric behavior. Insertion of a honeycomb essentially eliminated this behavior. Apparently, the 3-in.-thick honeycomb was just as effective as the 6-in.-thick honeycomb in eliminating the adverse effects of the cooler. 
Figures 8(b), 9(b), and 10(b) show the pitch flow-angle data in the test section for the different cooler/honeycomb configurations. The data show erratic behavior for the configurations without a honeycomb installed (with or without the cooler installed). The pitch angle profiles were the most smooth and most symmetrical when only the 6-in.-thick honeycomb was installed. The profiles with the cooler installed did appear to improve with the installation of the 6-in.-thick honeycomb. This was readily apparent at a test section Mach number of 0.1 (fig. 8(b)) and less apparent at Mach numbers of 0.3 and 0.5 (figs. 9(b) and 10(b)). The flow angles in the test section should be nearly constant at zero. This was generally true for the cases where the cooler was not installed, but deviations occurred when the cooler was installed and when test section Mach numbers were 0.3 or higher.

Figures 6(c) and 7(c) show axial turbulence intensities and figures 6(d) and 7(d) pitch turbulence intensities for the hot wire measurements taken in the SMIRT settling chamber. It was expected that improvements would be seen with the installation of a honeycomb and degradations with the insertion of the cooler. The data exhibited these exact trends. The worst axial and pitch turbulence intensities were seen when only the cooler was installed (roughly between 13 and 19 percent for both axial and pitch). The axial intensities with the cooler installed dropped to about 7 percent with either the 3- or 6-in. honeycomb installed, and the pitch intensities dropped to about 3 percent. From a turbulence reduction standpoint, the 3-in.-thick honeycomb performed just as well as the 6-in.-thick honeycomb in reducing the turbulence generated by the cooler. The lowest axial and pitch turbulence intensities were seen when neither the cooler nor a honeycomb was installed and when only the 6-in. honeycomb was installed (approximately 2 to 3 percent for both axial and pitch). It was also observed that the 6-in. honeycomb was effective in breaking up the large-scale turbulent structures in the ceiling and floor boundary layers. This was seen by comparing the intensity numbers near $X_{H W} / H_{S C}=0.0$ and 1.0 .

Figures $8(\mathrm{c}), 9(\mathrm{c})$, and $10(\mathrm{c})$ show axial turbulence intensities for the hot wire measurements taken in the SMIRT test section for the different cooler/honeycomb configurations and test section Mach numbers. The axial turbulence intensities generally decreased with the addition of a honeycomb and increased with the addition of the cooler. However, insertion of the cooler when the 6-in. honeycomb was present did not significantly increase the axial turbulence intensity. It was interesting to note that the axial data at test section Mach numbers of 0.3 and 0.5 exhibited clear evidence of boundary layer turbulence, but the data at $0.1 \mathrm{did}$ not. Another peculiarity of the $M_{T S}=0.1$ data was that it coalesced between 1 and 1.5 percent, whereas the data at the higher Mach numbers exhibited more variation. Additional measure ments in the test section at $M_{T S}=0.1$ were recommended, to validate these axial intensities.

Pitch turbulence intensities for the test section improved dramatically with the presence of a honeycomb (figs. 8(d), 9(d), and 10(d)). With only the cooler installed, values of pitch turbulence intensity in the test section core flow were between 2.8 and 4.8 percent. With the 6 -in. honeycomb installed, the intensity levels fell to within 0.5 and 1.2 percent. For Mach numbers of 0.3 and 0.5 , the pitch turbulence levels with no cooler and no honeycomb were comparable to those with both installed. However, at $M_{T S}=0.1$, the intensity level for the configuration with both installed was lower by 0.7 percent than the configuration with neither. The best pitch turbulence intensity levels occurred when only the 6 -in. honeycomb was installed. For this configuration, the levels in the core flow were around 0.3 percent.

\section{Concluding Remarks}

The Scale Model Icing Research Tunnel (SMIRT) was constructed to conduct studies of proposed flow improvements for the Icing Research Tunnel (IRT). Measurements were conducted in the SMIRT to provide baseline flow characteristics in the settling chamber and the test section. In addition, the effects of a honeycomb on flow quality were quantified. From these measurements, the following conclusions can be drawn:

1. Test section velocity ratio profiles computed from pressure measurements were flat and similar regardless of the cooler/honeycomb configuration for the two test section Mach numbers $(0.3$ and 0.5$)$ investigated.

2. Neither the 3-nor the 6-in. honeycomb was able to satisfactorily eliminate the mean axial velocity flow distortions in the settling chamber introduced by the $\mathrm{W}$-shaped cooler.

3. The 3-in. honeycomb proved to be just as effective as the 6-in. honeycomb in reducing settling chamber pitch flow angle, axial turbulence intensity, and pitch turbulence intensity.

4. Hot wire mean axial velocity profiles in the test section proved to be rather insensitive to the cooler/honeycomb configuration. In addition, gradients in the slope of these profiles were shown to be a result of flow interference introduced by the probe support and/or leakage through the tunnel wall/probe support penetration.

5. In the settling chamber and test section, hot wire mean axial velocities, pitch flow angles, and axial and pitch turbulence intensities were generally stable when neither the cooler nor a honeycomb was installed. 
6. Installation of the $\mathrm{W}$-shaped cooler introduced significant flow distortion into the settling chamber and test section in terms of hot wire mean axial velocity and pitch flow-angle profiles. Axial and pitch turbulence intensities were elevated to their highest levels when only the cooler was installed.

7. The installation of a honeycomb was found to have the favorable effect of reducing the pitch angle and turbulence intensity in both the settling chamber and test section.

Hot wire measurements presented here will eventually be compared with similar measurements made in the fullscale IRT. When fabrication of the fan leg is completed, the SMIRT will be assembled in a closed-loop circuit. The objectives of the first closed-loop test program will be to collect more data for comparison to actual IRT flow survey data. Favorable comparisons will validate the SMIRT as an accurate model of the full-scale IRT. If deemed an accurate model, the SMIRT will be used to test proposed full-scale facility modifications such as the addition of a honeycomb, test section leg corner fillets, and a new flat-faced cooler. If the scale model tests yield positive results, these additions may be implemented in the full-scale IRT, ensuring its status as the world's premier icing wind tunnel well into the next century.

\section{References}

1. Soeder, R.H.; and Andracchio, C.R.: NASA Lewis Icing Research Tunnel User Manual. NASA TM-102319, 1990. 2. Arrington, E. A.; Pickett, M.T.; and Sheldon D.W.: Flow Quality Studies of the NASA Lewis Research Center Icing Research Tunnel. NASA TM-106545, 1994.

3. Green, J.E., et al.: The Use of a Deep Honeycomb to Achieve High Flow Quality in the ARA 9'x8' Transonic Wind Tunnel. A93-14276, 1992.

4. TSI, Inc.: Model DAP IFA Thermal Anemometry Software Package Instruction Manual. Revision A, 1993. 
TABLE II.-HOT WIRE DATA ACQUISITION PARAMETERS

\begin{tabular}{|c|c|c|c|c|c|c|}
\hline \multirow{2}{*}{$\begin{array}{c}\text { Cooler } \\
\text { installed }\end{array}$} & \multirow{2}{*}{$\begin{array}{c}\text { Honeycomb } \\
\text { installed }\end{array}$} & \multicolumn{2}{|c|}{ Frequency } & \multirow[t]{2}{*}{ Gain } & \multirow{2}{*}{$\begin{array}{c}\text { Direct-current } \\
\text { offset, } \\
\text { V }\end{array}$} & \multirow[t]{2}{*}{ Probe } \\
\hline & & $\begin{array}{c}\text { Low pass, } \\
\mathrm{kHz}\end{array}$ & $\begin{array}{c}\text { Sampling rate, } \\
\mathrm{kHz}\end{array}$ & & & \\
\hline \multicolumn{7}{|c|}{ Measured at settling chamber; $M_{T S}=0.3$ and 0.5} \\
\hline No & No & 5 & 2 & 5 & 1 & $\mathrm{X}$-probe 2 \\
\hline No & 6-in. & 5 & 2 & 5 & 1 & X-probe 2 \\
\hline Yes & No & 5 & 2 & 6 & 1 & X-probe 1 \\
\hline Yes & 3 -in. & 5 & 2 & 6 & 1 & $\mathrm{X}$-probe 1 \\
\hline Yes & 6-in. & 5 & 2 & 6 & 1 & $\mathrm{X}$-probe 1 \\
\hline \multicolumn{7}{|c|}{ Measured at test section; $M_{T S}=0.1$ and 0.3} \\
\hline No & No & 5 & 2 & 5 & 1 & $\mathrm{X}$-probe 2 \\
\hline No & 6-in. & 5 & 2 & 5 & 1 & $\mathrm{X}$-probe 2 \\
\hline Yes & No & 5 & 2 & 5 & 1 & $\mathrm{X}$-probe 2 \\
\hline Yes & 6-in. & 2 & 1 & 5 & 1 & $\mathrm{X}$-probe 2 \\
\hline No & 6-in. & 2 & 1 & 8 & 2 & Single wire ${ }^{a}$ \\
\hline \multicolumn{7}{|c|}{ Measured at test section; $M_{T S}=0.5$} \\
\hline No & No & 2 & 1 & 10 & 2 & $\mathrm{X}$-probe 2 \\
\hline No & 6-in. & 2 & 1 & 10 & 2 & $\mathrm{X}$-probe 2 \\
\hline Yes & No & 2 & 1 & 10 & 2 & $\mathrm{X}$-probe 2 \\
\hline Yes & 6-in. & 2 & 1 & 5 & 1 & $\mathrm{X}$-probe 2 \\
\hline No & 6-in. & 2 & 1 & 8 & 2 & Single wire ${ }^{\mathrm{a}}$ \\
\hline
\end{tabular}

${ }^{\mathrm{a}}$ Inverted hot wire probe measurements. 


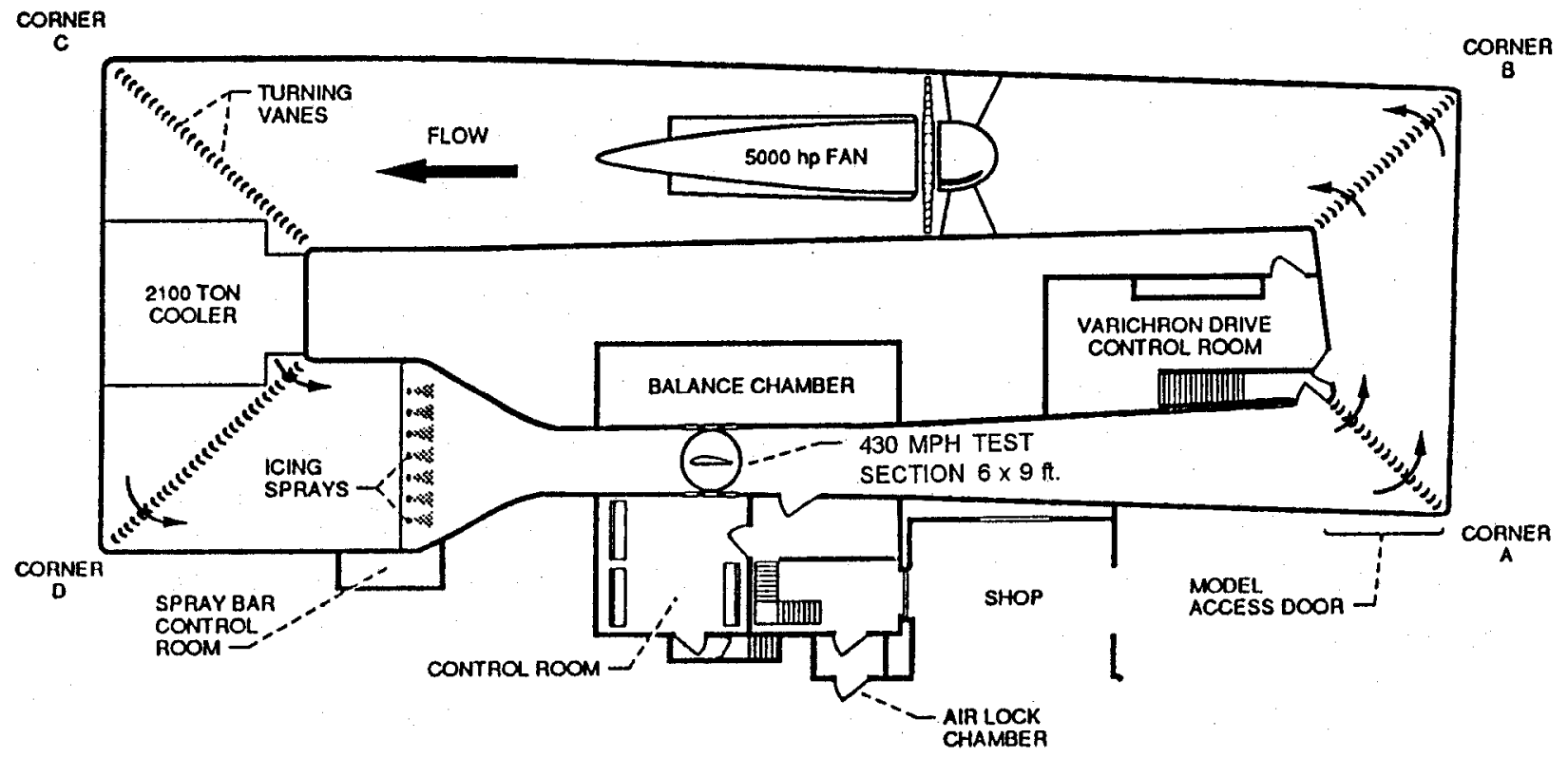

Figure 1.-Plan view of NASA Lewis' Icing Research Tunnel.

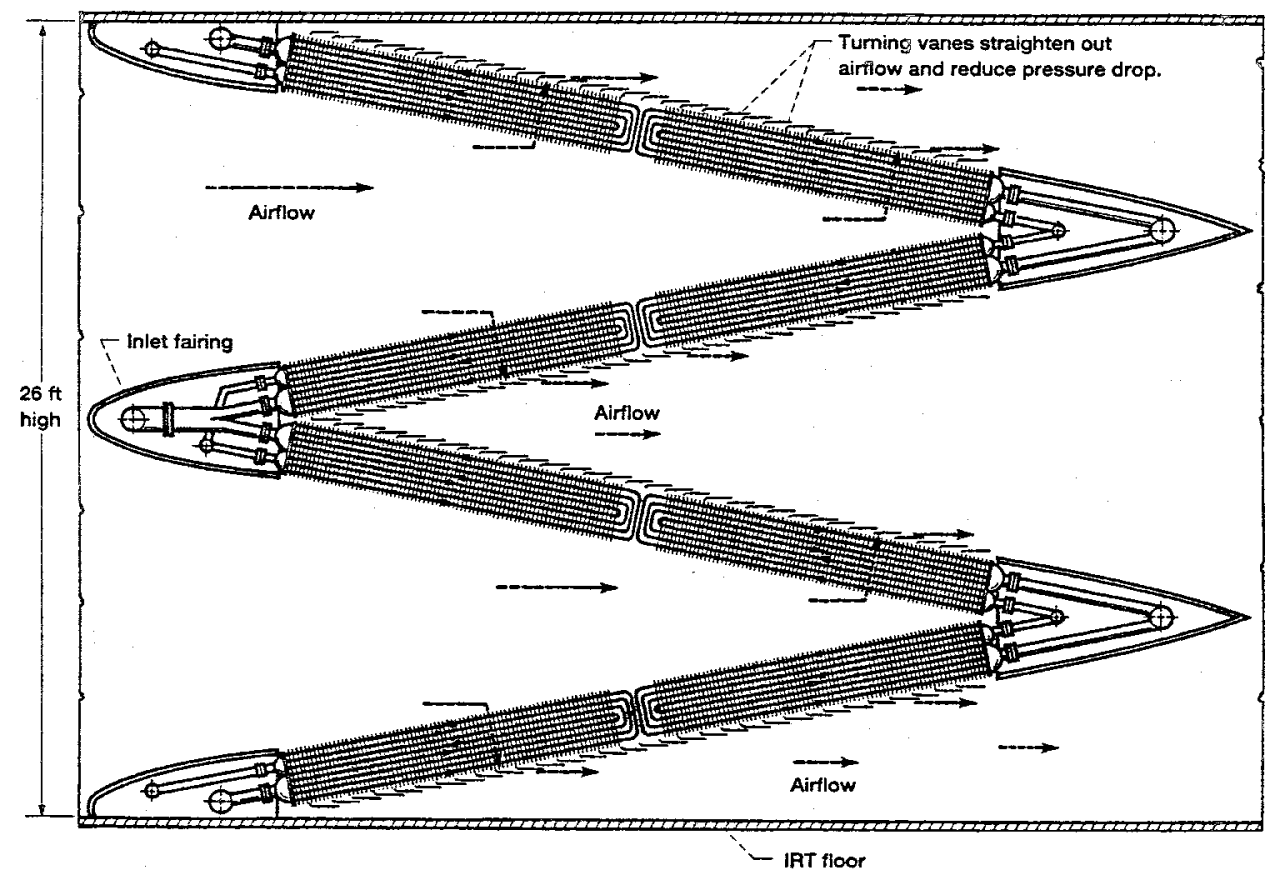

Figure 2.-Elevation view of the Icing Research Tunnel cooler. 


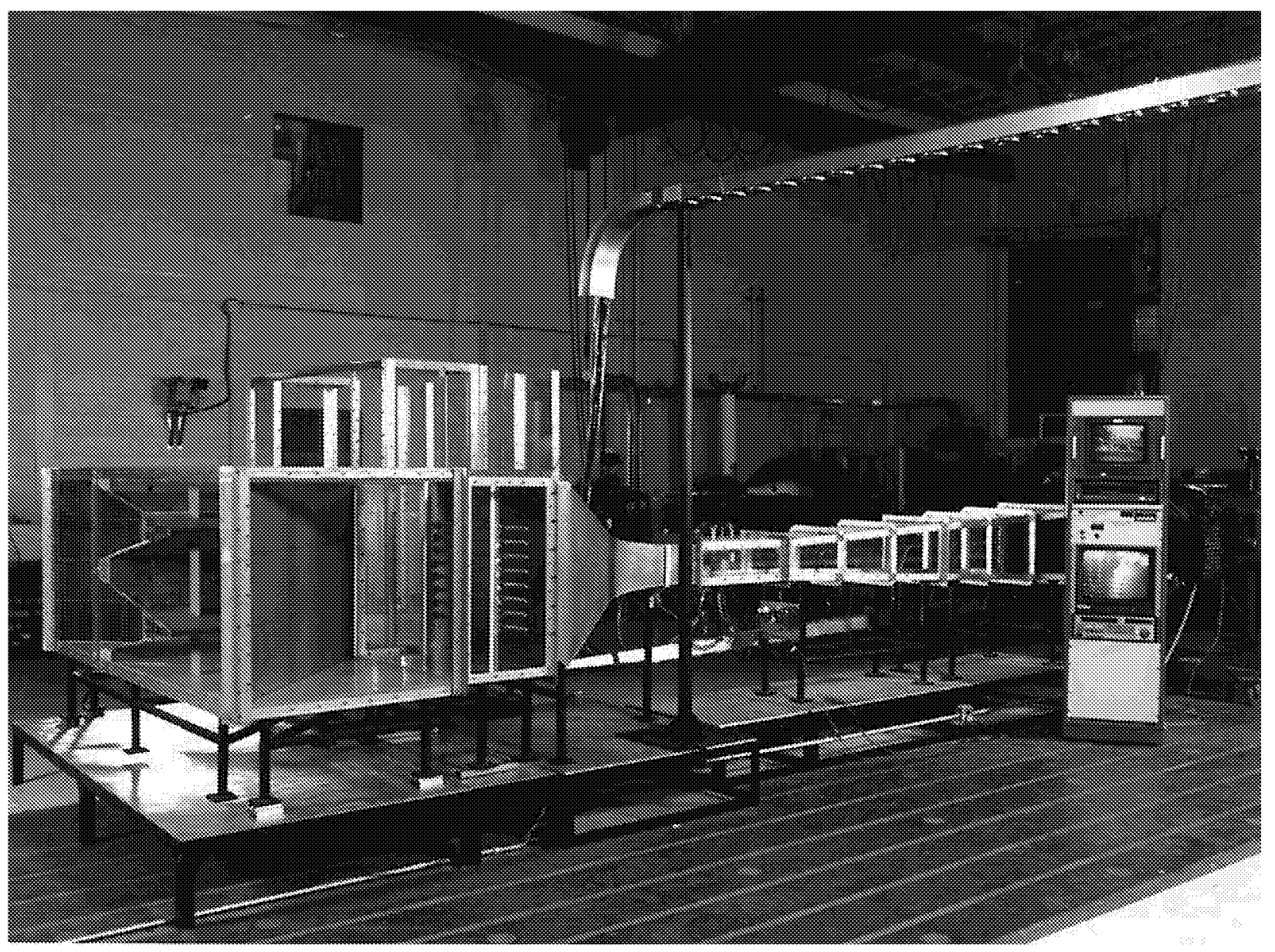

Figure 3.- The Scale Model Icing Research Tunnel (SMIRT) in open-loop configuration. 


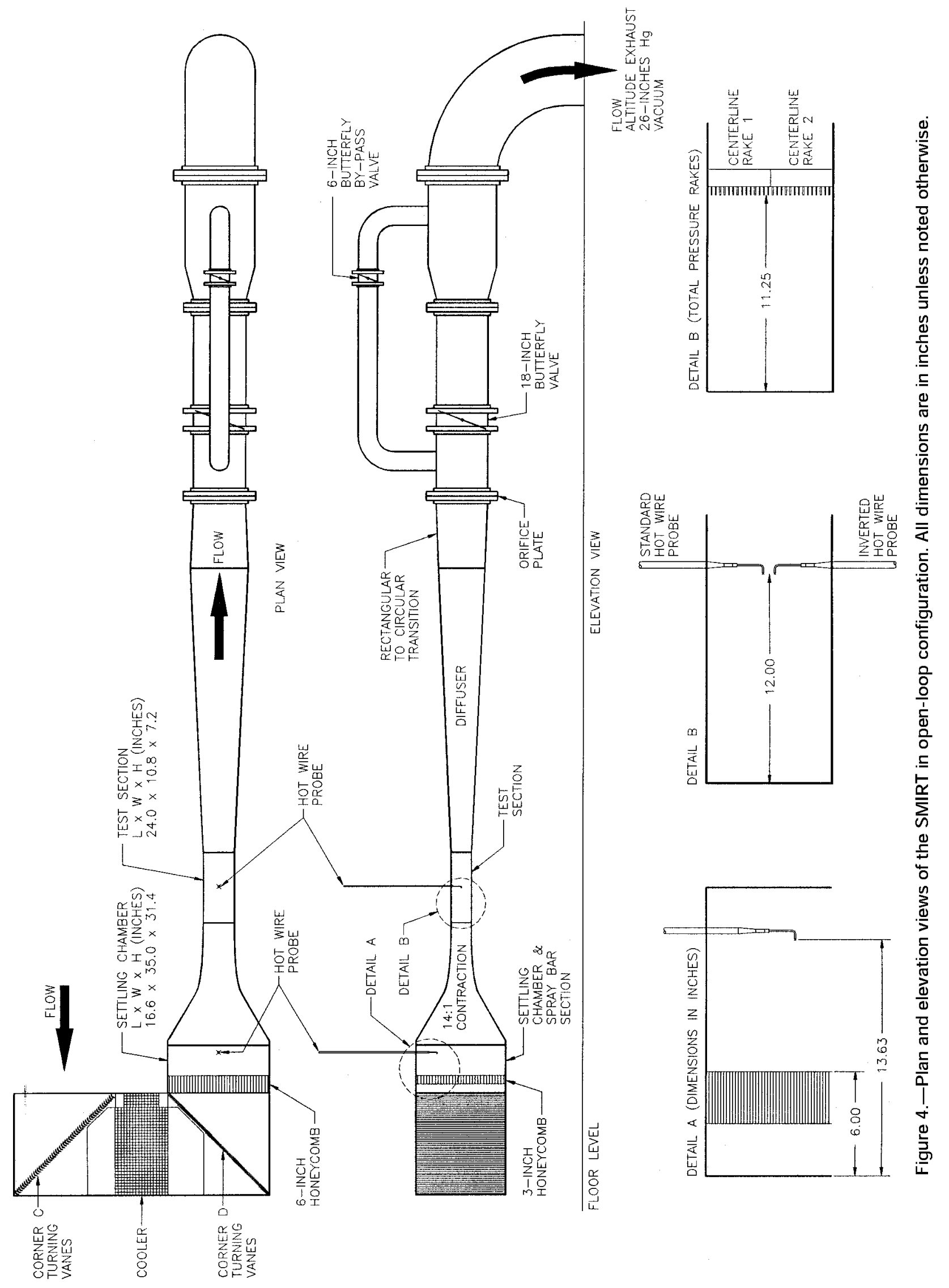




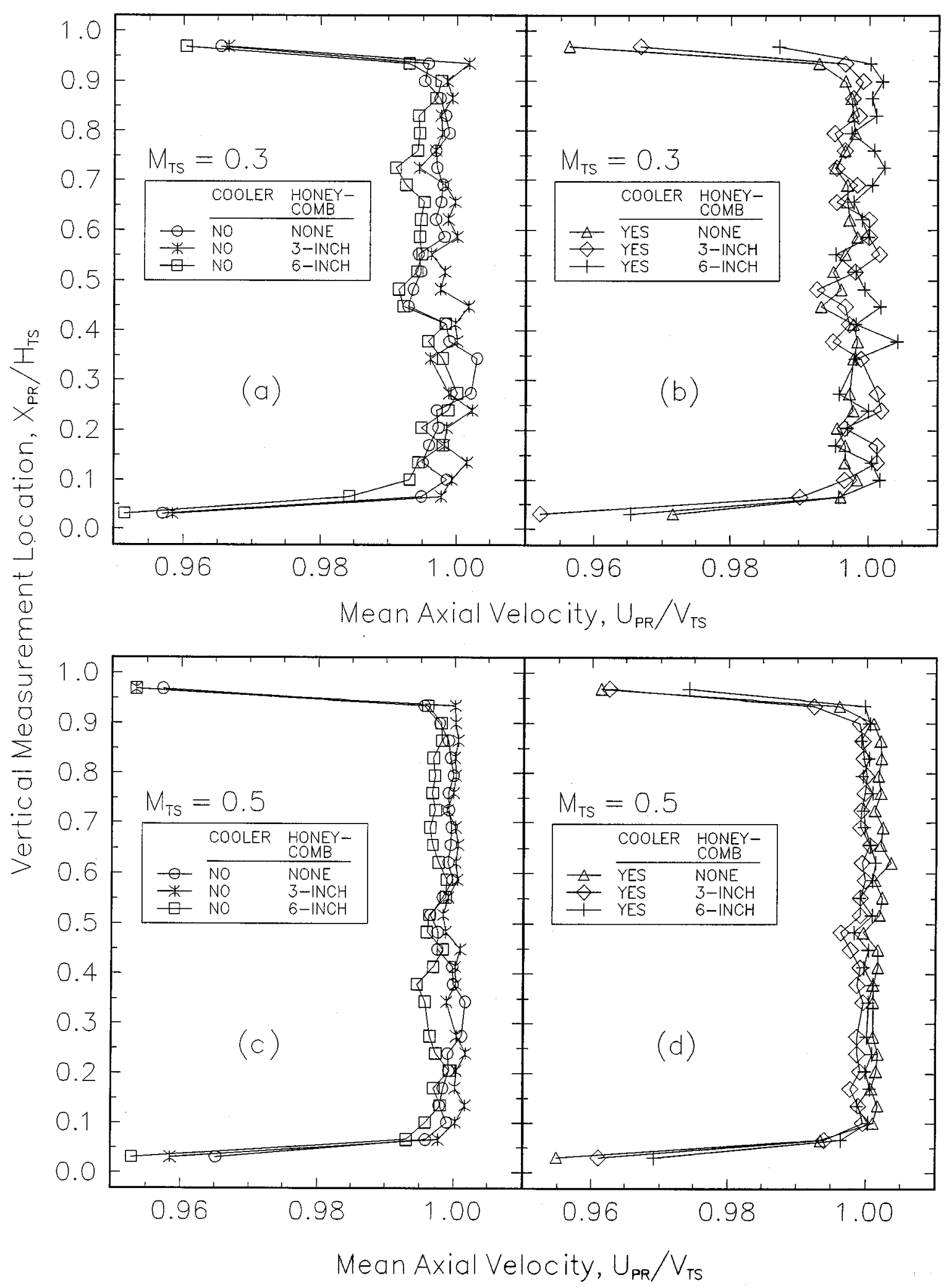

Figure 5.-Axial velocity profiles computed from pressure data in the SMIRT test section. (a) Test section Mach number, $M_{T S}, 0.3$; cooler not installed. (b) $M_{T S}, 0.3$; cooler installed. (c) $M_{T S}, 0.5$; cooler not installed. (d) $M_{T S}, 0.5$; cooler installed. 


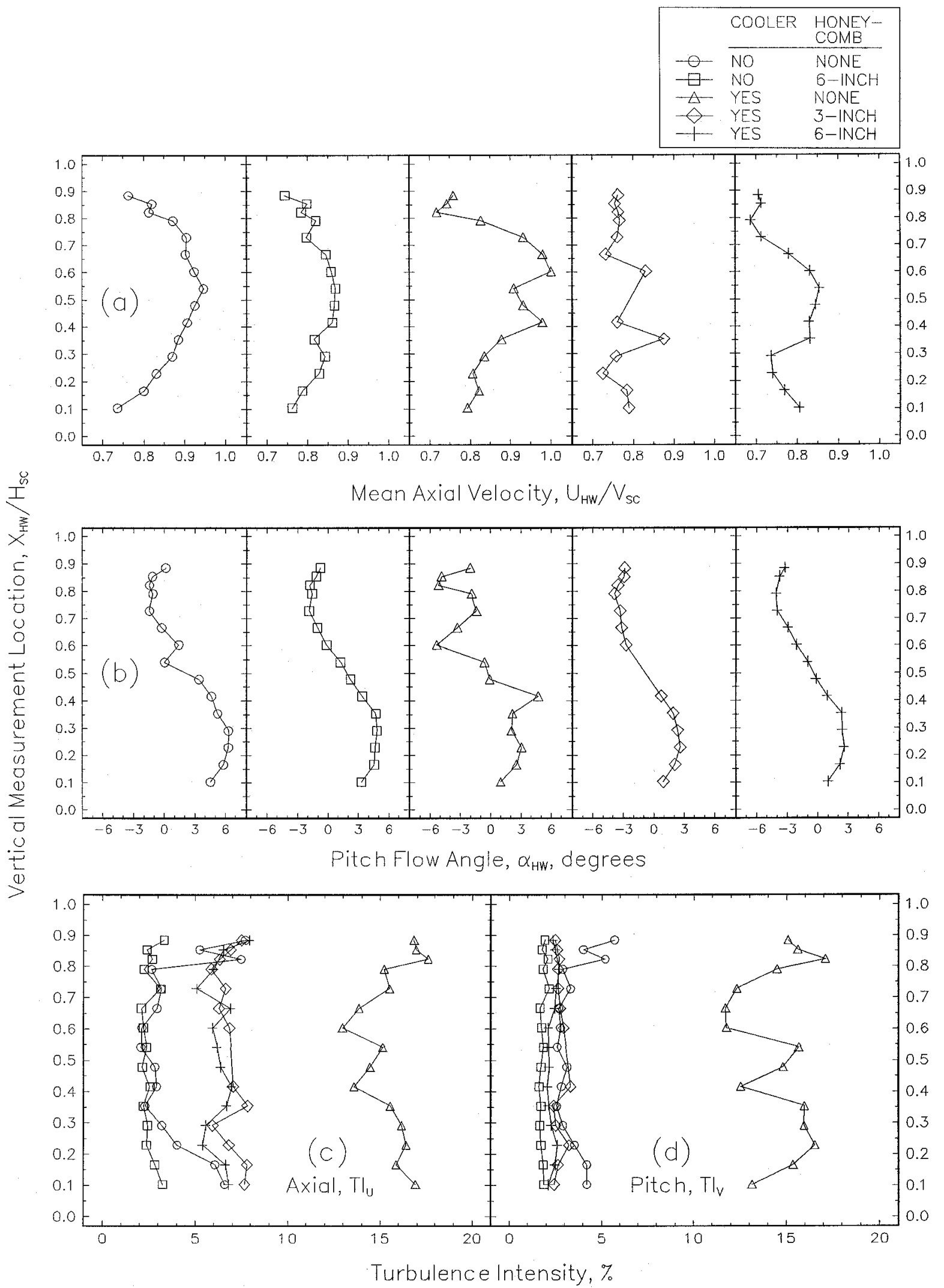

Figure 6.-Hot wire data recorded in the SMIRT settling chamber at a test section Mach number, $M_{T S}$, of 0.3 .

(a) Mean axial velocity normalized by a settling chamber velocity, $V_{S C}$, of $32 \mathrm{ft} / \mathrm{sec}$. (b) Pitch flow angle.

(c) Axial turbulence intensity. (d) Pitch turbulence intensity. 


\begin{tabular}{|c|c|c|}
\hline & COOLER & $\begin{array}{l}\text { HONEY- } \\
\text { COMB } \\
\end{array}$ \\
\hline $\begin{array}{l}\stackrel{\theta}{\square} \\
\stackrel{\square}{\Delta} \\
\stackrel{\Delta}{r}\end{array}$ & $\begin{array}{l}\text { NO } \\
\text { NO } \\
\text { YES } \\
\text { YES } \\
\text { YES }\end{array}$ & $\begin{array}{l}\text { NONE } \\
6-I N C H \\
\text { NONE } \\
3-I N C H \\
6-I N C H\end{array}$ \\
\hline
\end{tabular}
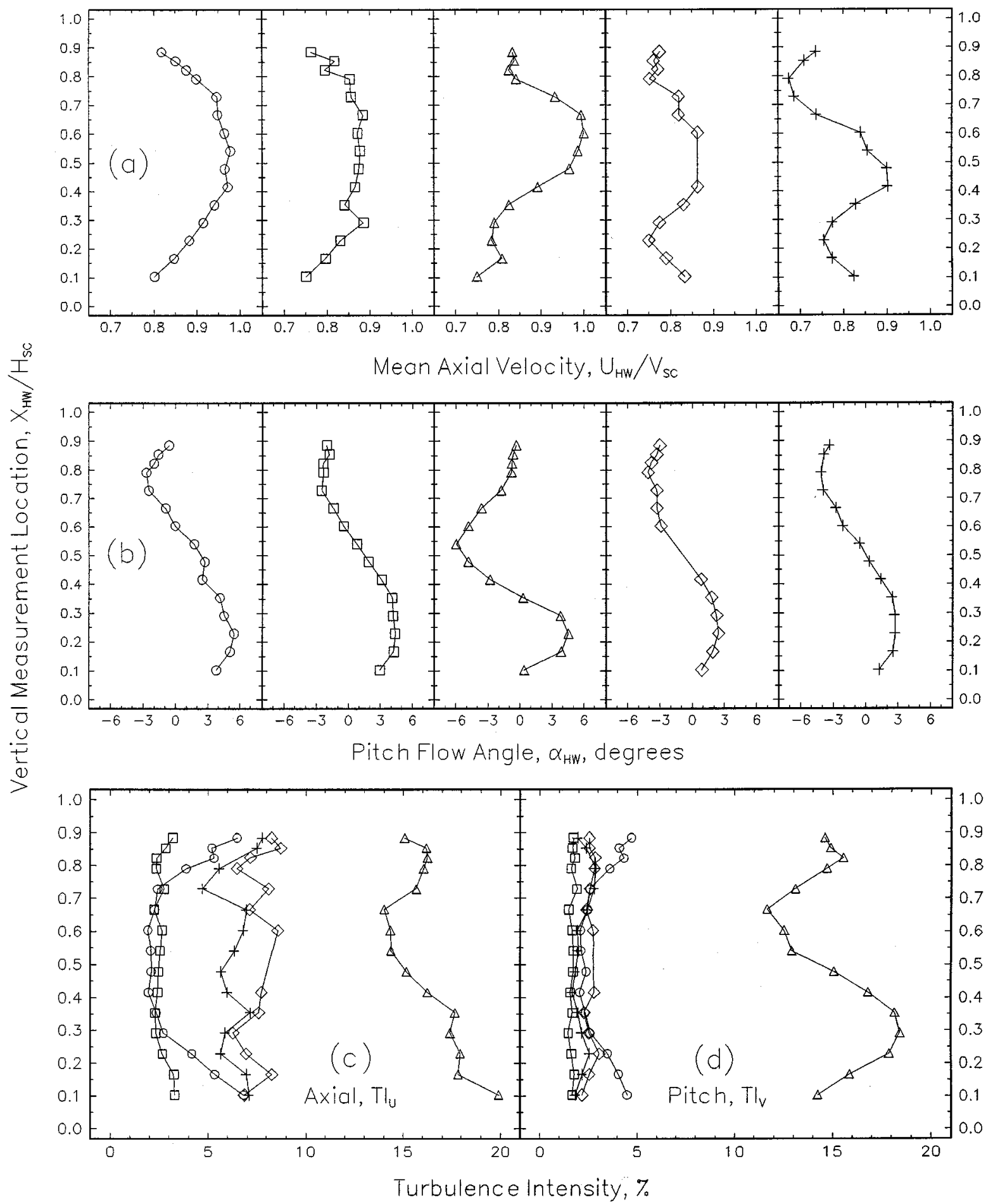

Figure 7.- Hot wire data recorded in the SMIRT settling chamber at a test section Mach number, $M_{T S}$, of 0.5 . (a) Mean axial velocity normalized by a settling chamber velocity, $V_{S C}$, of $46 \mathrm{ft} / \mathrm{sec}$. (b) Pitch flow angle. (c) Axial turbulence intensity. (d) Pitch turbulence intensity. 


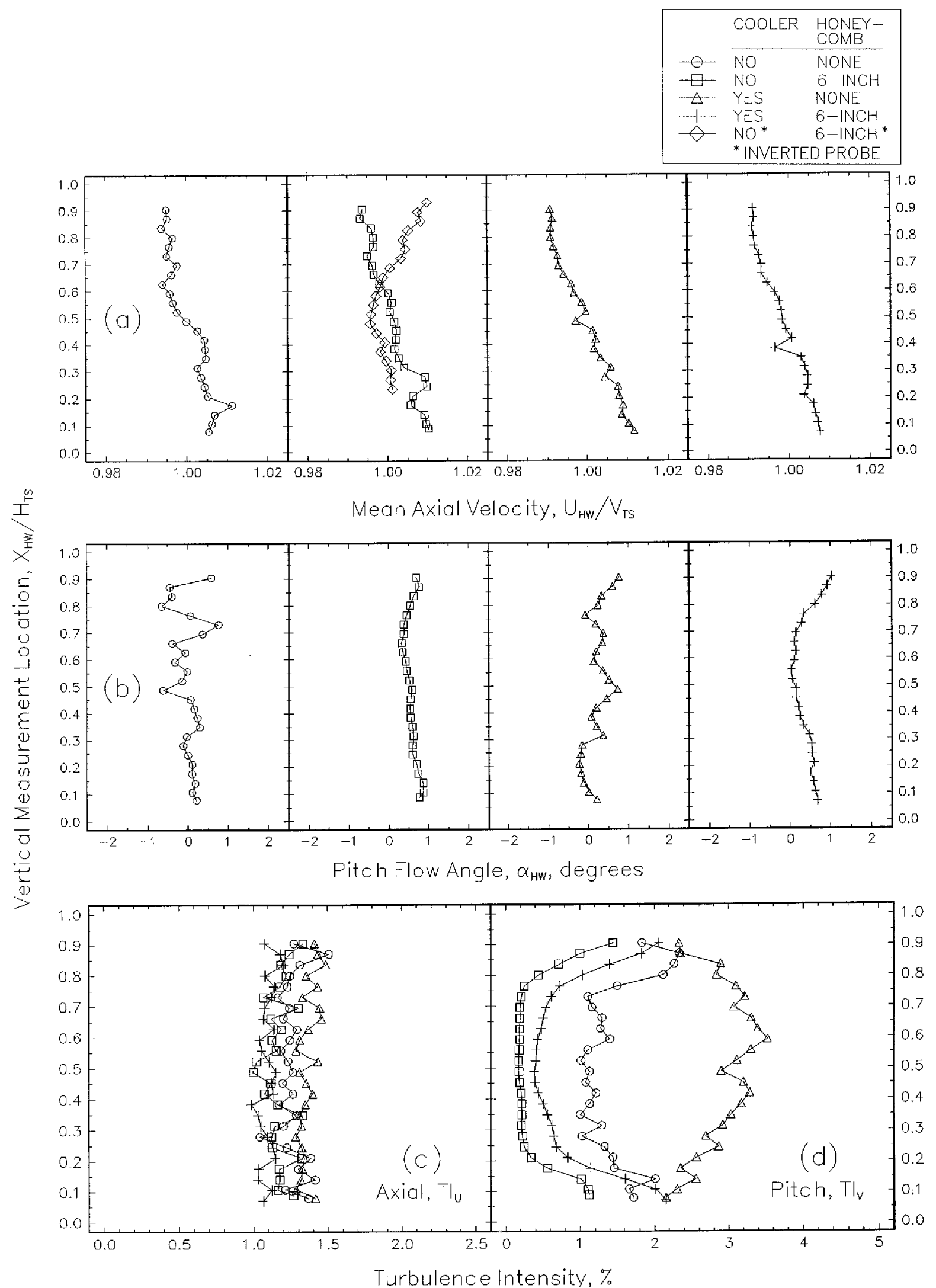

Figure 8.-Hot wire data recorded in the SMIRT test section at a test section Mach number, $M_{T S}$, of 0.1.

(a) Mean axial velocity normalized by a test section velocity, $V_{T S}$, of $113 \mathrm{ft} / \mathrm{sec}$. (b) Pitch flow angle.

(c) Axial turbulence intensity. (d) Pitch turbulence intensity. 


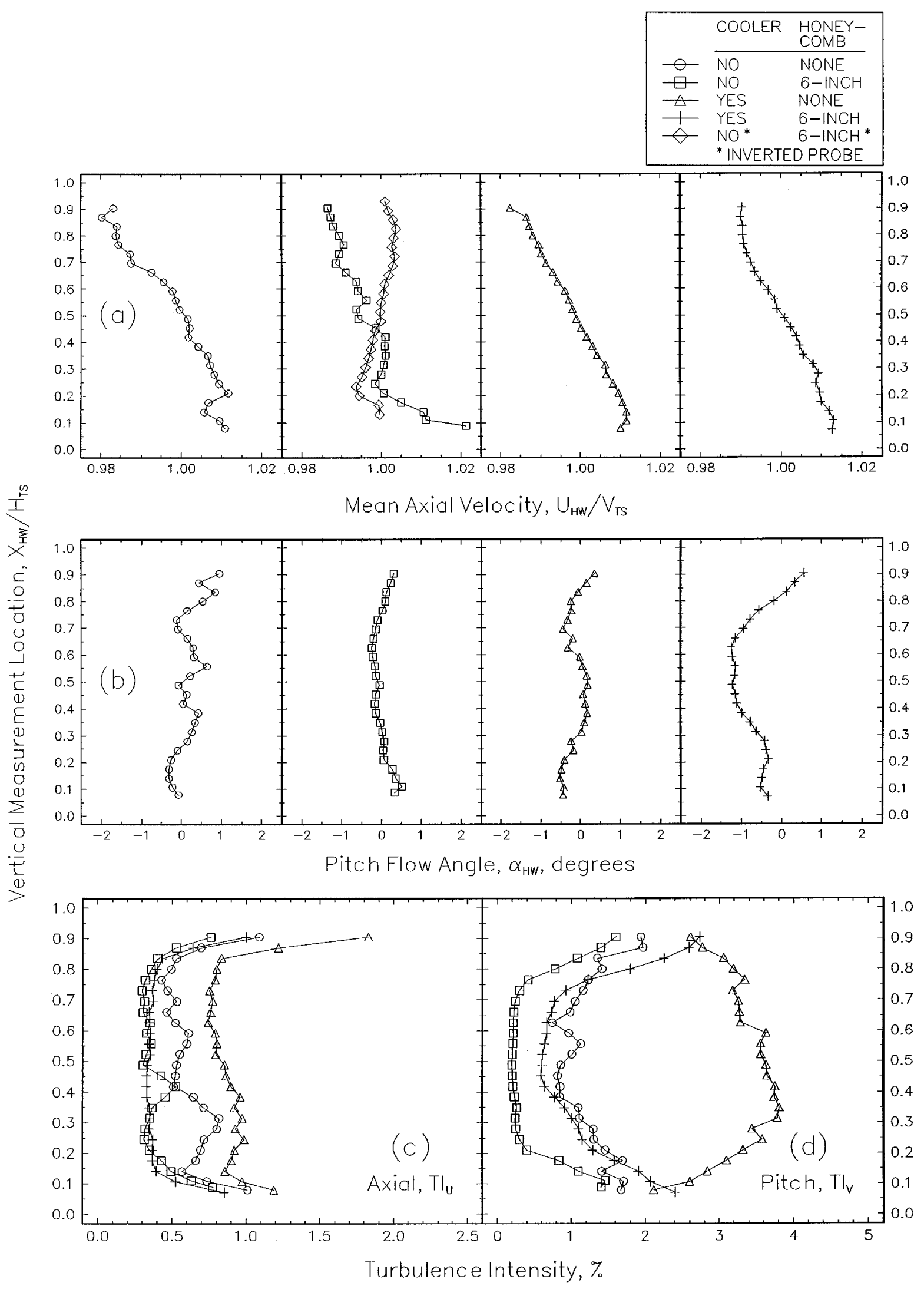

Figure 9.-Hot wire data recorded in the SMIRT test section at a test section Mach number, $M_{T S}$, of 0.3. (a) Mean axial velocity normalized by a test section velocity, $V_{T S}$, of $335 \mathrm{ft} / \mathrm{sec}$. (b) Pitch flow angle.

(c) Axial turbulence intensity. (d) Pitch turbulence intensity. 


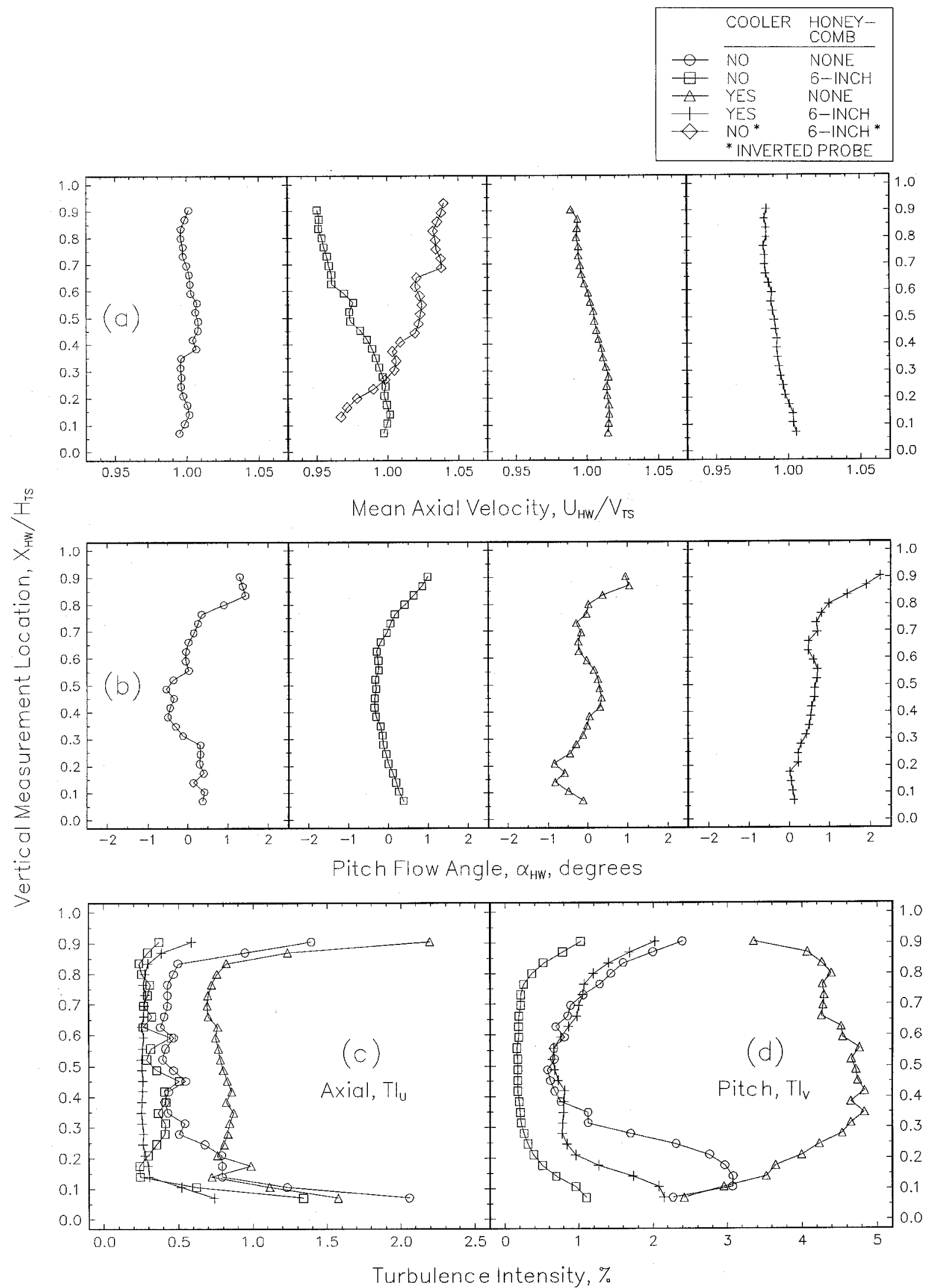

Figure 10.-Hot wire data recorded in the SMIRT test section at a test section Mach number, $M_{T S}$, of 0.5 . (a) Mean axial velocity normalized by a test section velocity, $V_{T S}$, of $555 \mathrm{ft} / \mathrm{sec}$. (b) Pitch flow angle.

(c) Axial turbulence intensity. (d) Pitch turbulence intensity. 
Public reporting burden for this collection of information is estimated to average 1 hour per response, including the time for reviewing instructions, searching existing data sources, gathering and maintaining the data needed, and completing and reviewing the collection of information. Send comments regarding this burden estimate or any other aspect of this
collection of information, including suggestions for reducing this burden, to Washington Headquarters Services. Directorate for Information Operations and Reports, 1215 Jefferson Davis Highway, Suite 1204, Arlington, VA 22202-4302, and to the Office of Management and Budget Paperwork Reduction Project (0704-0188), Washington, DC 20503

\begin{tabular}{|l|c|c|}
\hline 1. AGENCY USE ONLY (Leave blank) & $\begin{array}{c}\text { 2. REPORT DATE } \\
\text { January } 1999\end{array}$ & $\begin{array}{c}\text { 3. REPORT TYPE AND DATES COVERED } \\
\text { Final Contractor Report }\end{array}$
\end{tabular}

\section{TITLE AND SUBTITLE}

Flow Quality Measurements in an Aerodynamic Model of

NASA Lewis' Icing Research Tunnel

6. AUTHOR(S)

Victor A. Canacci and Jose C. Gonsalez
5. FUNDING NUMBERS

WU-523-91-13-00

NAS3-27186
7. PERFORMING ORGANIZATION NAME(S) AND ADDRESS(ES)

NYMA, Inc.

2001 Aerospace Parkway

Brook Park, Ohio 44142

9. SPONSORING/MONITORING AGENCY NAME(S) AND ADDRESS(ES)

National Aeronautics and Space Administration

Lewis Research Center

Cleveland, Ohio 44135-3191
8. PERFORMING ORGANIZATION REPORT NUMBER

E-10790

10. SPONSORING/MONITORING AGENCY REPORT NUMBER

NASA CR_-1999-202353

\section{SUPPLEMENTARY NOTES}

Prepared for the 31st Joint Propulsion Conference and Exhibit cosponsored by AIAA, ASME, SAE, and ASEE, San Diego, California, July 10-12, 1995. Project Manager, Sandra L. Hardy, Facilities and Test Engineering Division, NASA Lewis Research Center, organization code 7560, (216) 433-2278.

12a. DISTRIBUTION/AVAILABILITY STATEMENT 12b. DISTRIBUTION CODE

Unclassified - Unlimited

Subject Category: 09

Distribution: Nonstandard

This publication is available from the NASA Center for AeroSpace Information, (301) 621-0390.

\section{ABSTRACT (Maximum 200 words)}

As part of an ongoing effort to improve the aerodynamic flow characteristics of the Icing Research Tunnel (IRT), a modular scale model of the facility was fabricated. This $1 / 10$ th-scale model was used to gain further understanding of the flow characteristics in the IRT. The model was outfitted with instrumentation and data acquisition systems to determine pressures, velocities, and flow angles in the settling chamber and test section. Parametric flow quality studies involving the insertion and removal of a model of the IRT's distinctive heat exchanger (cooler) and/or of a honeycomb in the settling chamber were performed. These experiments illustrate the resulting improvement or degradation in flow quality.

\section{SUBJECT TERMS}

Wind tunnel; Scale model wind tunnel; Icing research; Hot wire anemometry;

Heat exchanger; Honeycomb; Flow conditioners; Flow quality measurements

\begin{tabular}{|c|c|}
\hline $\begin{array}{c}\text { 17. SECURITY CLASSIFICATION } \\
\text { OF REPORT } \\
\text { Unclassified }\end{array}$ & $\begin{array}{c}\text { 18. SECURITY CLASSIFICATION } \\
\text { OF THIS PAGE } \\
\text { Unclassified }\end{array}$ \\
\hline
\end{tabular}

19. SECURITY CLASSIFICATION
OF ABSTRACT
Unclassified

Unclassified 